\title{
3 \\ Love, Polygyny, and HIV
}

Miriam met her first husband in 1991 when she was returning home to Tari, after having lived in Mt. Hagen with her uncle's family for almost two years. As she recalled, there had been tribal fighting along the road, and the area was unnaturally quiet. A number of bridges had been sabotaged, forcing Miriam and her uncle to leave their PMV and walk the rest of the way. The man who was to become her husband, armed and dressed as a warrior, offered to help carry their bags and accompany them safely through the conflict zone. Thereafter she repeatedly ran into him and his sister in Tari, and they would all walk around town together. Before they married, "He would boss me around (Em save bossim mi)," she said matter-of-factly, without resentment. "He would say, 'You can't go into Tari all the time.' He would say that he was going to marry me, and so I had to stay at home." (The implication here is that young women go into town to make themselves visible to potential suitors, and so if she continued to go to Tari, she would have been presenting herself as still available for marriage.)

The 2004 interview protocol included the question, "Can you tell me about a time when you were married and your husband did something that made you really happy?" Most women responded with stories about receiving gifts of money or clothing, or being praised or appreciated by a husband in front of his family. In contrast, Miriam told me about the time he introduced her to mutual oral sex. As she described it, they had been washing clothes on a beautiful day at a small, remote waterfall. "He just about died-he expressed so much pleasure. And he said things to me like, 'Oh Miriam, my love, this is too much. I am dying!' And I felt the same way, and we both finished our worries (pinisim wari bilong mipela, a euphemism for orgasm). We were really joined. ... I still think about the sex we had together. It really joined us. What we did together was against Huli custom (brukim lo bilong mipela), and I don't think that other Huli spouses do the things we did together. We were really joined." 
When Miriam states that oral sex is "against Huli custom," she is referring to the traditional ethic of gender avoidance, in which husbands and wives lived in different houses, cooked and ate separately, and generally conducted their lives in separate spheres. This ethic of distance was also supposed to inform marital sexual practice: sex was supposed to take place only a few days each month and only genital-to-genital sex was condoned. Some older male interviewees also spoke of lifting themselves up on their forearms to minimize bodily contact, or of rubbing a special red tree oil on their bellies and thighs before sex as a kind of protective barrier. These spatio-sexual distancing practices were intended to preserve a man's health, youthful vigor, martial strength, and social appeal.

Marriage has changed significantly since the pre- and early postcolonial period; nevertheless, only a few women in my 2004 interview sample spoke of having oral sex with their husbands, and all of them, like Miriam, described this as "against custom," "unnatural" (because not aimed at reproduction), "white" (because seen in pornographic magazines and films in which the performers were white), and something only sex workers did. While a husband was entitled to sex because he had paid bridewealth, women said, he wasn't entitled to that kind of sex; rather, he was entitled to reproduction-oriented sex. Most men in the sample, though not all, said that they engaged in "customary sex" with their wives, and that passenger women were for experimenting with "style-style sex," thus reinforcing the notion that sex with wives was for reproduction and that only rebellious and dissolute women engaged in non-customary sex. Some men also asserted that a man was asking for trouble if he introduced his wife to new sexual positions and practices: she might be more likely to seek out pleasure elsewhere, and, knowledgeable about his own predilections, she would be better able to manipulate and dominate him (Wardlow 2008). Some also worried that in anger a wife might publicly announce a husband's non-traditional sexual proclivities in order to humiliate him. In short, the 2004 interviews suggested that sexual practices that were perceived as "non-traditional" could complicate marital relations of power by introducing new emotional and psychological vulnerabilities into marriage. They were therefore to be avoided. One important consequence was that wives like Miriam, who did engage in non-customary practices, often felt that they had achieved a special and rare degree of intimacy, shared understanding, and trust in their marriages that other couples did not have. As Miriam put it, "We had secret pleasures togetherwe did things that other people don't know about. So we were really joined."

Miriam's husband worked as a coffee buyer, and he used some of his profits to set up a small trade store in Tari, which he trusted Miriam to manage when he was away. His willingness to leave her in charge of their store, and her sense that they were striving as a team for upward mobility, further reinforced Miriam's confidence and joy in having a real partnership with her husband.

It came as a complete shock to her, then, when without warning or discussion, he took a second wife. He had slept with other women before, she knew, and, in 
fact, she had once caught him in the act and "poked" his sexual partner with a knife (Huli women use the verb pokim to mean a light stab that draws blood, and might require stitches, but does not result in life-threatening injuries). However, he explained his sexual dalliances as meaningless stopgap measures made necessary because of his and Miriam's adherence to pregnancy and post-partum sexual abstinence rules, an explanation she accepted. Surreptitiously assembling bridewealth and taking another wife was another matter entirely.

Feeling profoundly betrayed, Miriam reacted by bekim bek (to get back at someone, to retaliate by engaging in equivalent hurtful behavior, usually used by Huli women to refer to revenge sex): "I was really angry with my husband, and so I went and had sex with another man. But my father found out, and he hit me and broke my nose, and then he told my husband." Her husband demanded a divorce and the return of all twenty-four of his bridewealth pigs. Because Miriam had given him three children, in the end he only received eight pigs, plus an additional seven from Miriam's sexual partner as compensation for the adultery.

Miriam was despondent after the demise of this marriage. She had expected that her infidelity might result in a physical altercation with her husband, but that he would eventually understand and forgive the rage that had driven her retaliatory behavior: "We were really joined. It should have been hard to rip us apart, hard to make him kick me out." But she had underestimated the anger he would feel at being humiliated by her infidelity and at her unwillingness to accept that, as a man, he had a right to take another wife, and, as a successful businessman, of course he had done so.

"So after that I just passengered around. I slept around with a lot of men. I went to dawe anda. I drank beer. I slept anywhere in any house." She lived for a while in Mt. Hagen, where a female cousin acted as a kind of sexual intermediary, informing her about men who were interested in her, and then taking a share of the money she made. Eventually, she moved back to Tari, traveled from one dawe anda to another, and met the man who became her second husband: "At one dawe anda, I was playing cards and a man came and sat behind me and gave me tips, told me what cards to play. And I won, so I gave him ten kina. And right then and there he announced that I was his wife. So I went home with him, and I've been with him for three years."

This "husband" had not given bridewealth for her, however, and he continued to attend dawe anda, where he occasionally had sex with other women:

I know he has sex with other women, so I don't trust him, and it's hard for us to have private thoughts together. My first husband-it was like we had one name, one thought (wanpela nem, wanpela tingting; this could also be translated as having the same name, the same thought or way of thinking). But my thoughts are not joined with my second husband. I have wanted to teach him about the sexual things I did with my first husband, but I can't trust him. If I taught him he might go try them with other women, experience all kinds of pleasure with them, and then leave me altogether. 
Notice here Miriam's assumptions that her second husband doesn't already know about non-customary sexual practices and that experiencing them would dramatically transform his relationship to his own desiring body. These assumptions speak, I think, to the pleasure, danger, and secrecy that Huli, perhaps especially women, associated with non-reproductive sex at that time.

Of the thirty HIV-positive women I interviewed in 2012 and 2013, at least twentytwo had been infected with HIV by their husbands. (Three more had been married to men who were also HIV-positive and who had histories of extramarital partners. Upon learning of their husband's infidelities, these women, much like Miriam, had bekim bek, and they did not know if they had contracted HIV from their husbands or from their subsequent partners.) Clearly, marriage is a site of HIV vulnerability, and the directionality of transmission is most often from husbands to wives. It is therefore important to understand how HIV vulnerability is produced within marriage, and Miriam's story introduces a number of important themes. For example, as a successful coffee buyer who had disposable income and was often away from home, Miriam's husband in fact had many extramarital partners (she learned of this after the dissolution of her marriage). Moreover, his polygyny also contributed to her HIV vulnerability, not, in this case, by introducing a new sexual partner into the marriage, but rather by betraying the kind of marriage Miriam thought they had, and thereby motivating her to engage in revenge sex. Her later depression, and her means of expressing and coping with it through a physically and sexually vagabond existence, can also be attributed to the demise of this marriage. And the demise of this marriage ultimately resulted from her and her husband's conflicting ideas about the nature of their marriage. They did not, in fact, have wanpela tingting when it came to polygyny, for example. In other words, marriage is a site of HIV vulnerability in part because Huli men and women often have very different and conflicting aspirations for marriage, and when these opposing desires and assumptions collide, it can result in either or both spouses seeking out extramarital partners.

\section{AIDS PREVENTION AND THE PROMOTION \\ OF COMPANIONATE MARRIAGE}

It is also important to examine marriage as a site of HIV vulnerability because AIDS prevention in the Tari area has focused not only on urging couples to "Be faithful" - the B of so-called ABC campaigns-but also on trying to teach them what loving, equitable, and health-promoting marriages should look like. For example, Population Services International (PSI) has developed and carries out four-day marital relationship training workshops for married couples in Hela that aim to equip them with a range of skills: active listening, using "I-statements" 
instead of "You-statements," understanding the concepts of intimacy and empathy and how to increase them, goal-setting for couples, and conflict de-escalation. ${ }^{2}$ Marital relations in Papua New Guinea are often represented in the HIV/AIDS policy literature as pathogenic (see also Shih et al. 2017), and AIDS education, as well as gender-based violence reduction initiatives, have been animated by what might be called, borrowing from Tania Li (2007), a "will to improve" marital intimacy. Much as Anne Esacove observes, "policy prescribes and ultimately attempts to create 'modern' relationships as the solution to HIV/AIDS. . . . Reaching this prescriptive ideal requires a reorganization of intimate relationships" (Esacove 2016). Such interventions draw on a therapeutic ethos (Spronk 2009) and are often informed by a tacit evolutionist teleology of intimacy in which AIDS (and genderbased violence) might be prevented if people could learn to do heterosexual marriage in more modern, Western ways.

The marital model being promoted and taught in such workshops is often referred to in the social science literature as companionate marriage-that is, marriage in which "emotional closeness is understood to be both one of the primary measures of success in marriage and a central practice through which the relationship is constituted and reinforced" (Wardlow and Hirsch 2006: 4). The theorization of companionate marriage is often traced back to Anthony Giddens's 1992 book The Transformation of Intimacy: Sexuality, Love, and Eroticism in Modern Societies, in which he argued that "modern societies"-by which he meant Western, or Northern, societies-had undergone a significant constellation of social, economic, and ideological changes, such that romantic love, or what he called a "pure relationship," had achieved a kind of ascendency and had become the precursor to, and foundation for, intimate relationships like marriage. A pure relationship, he said, is created and sustained by sentiment-the self's emotional fulfillment by the other's unique qualities. With sentiment at its core, companionate marriage can be distinguished from marital forms in which, for example, political or economic alliances between families are prioritized.

Although it is being promoted in Papua New Guinea, it is important to note that feminist and queer theorists have advanced important critiques of this marital form. Scholars have observed, for example, that the valorization of companionate marriage is a fundamental component of a modern heteronormative narrative that also includes the assumption that monogamous intimacy between two people is the one and only path to happiness (Berlant 1998, Ahmed 2010, Wilson 2012). As Lauren Berlant puts it, "desires for intimacy that bypass the couple or the life narrative it generates have no alternative plots"; "only one plot counts as 'life' (first comes love, then . . . )," and departing from the love-then-marriage-then-babycarriage trajectory is viewed as not a real life: "Those who don't or can't find their way in that story - the queers, the single, the something else-can become so easily unimaginable, even often to themselves" (1998: 285-86). Sara Ahmed, for her part, expresses skepticism about "the happiness turn" (Ahmed 2010: 3) and the 
centrality of companionate marriage to it. What she calls the happiness turn refers to the recent global wholesale cultural embrace of happiness as that which "gives purpose, meaning and order to human life" (1), so that there are now global surveys, academic journals, and an enormous therapeutic industry devoted to measuring, analyzing, and promoting happiness and the ways to achieve it. She notes that "one of the primary happiness indicators is marriage" (6), and she traces the ways that "happiness promotion becomes very quickly the promotion of certain types of families" (11). In other words, the promise and hegemonic value of happiness legitimates the normalization of families founded on companionate marriage, and the delegitimation of other forms of intimacy. Finally, anthropologists have pointed out the fragility of marital forms based on happy, gratifying sentiment: if the marriage ceases to produce happiness, it can be dissolved, with sometimes devastating consequences for women, who are often dependent on husbands, both economically and, in some contexts, reputationally (Wardlow and Hirsch 2006).

It is important to note that the globalization of companionate conjugality as happiness-producing, or "the only plot," works to exclude or delegitimize not only queer intimacies, but also other non-Western/Northern forms of heterosexual intimacy. The heteronormative conjugal couple assumed by critiques such as Berlant's and Ahmed's is a Western/Northern one. In contrast, while the Huli might also be considered strongly heteronormative, their precolonial philosophies and practices regarding conjugality do not accord with the companionate models of marriage promulgated in Papua New Guinea by Christian churches, state institutions, or, more recently, AIDS education programming. Central to the companionate marriage model promoted by these various institutions is the idea that "real" intimacy is what might be called proximate intimacy, in which affective closeness between spouses is achieved through living together, face-to-face communication, shared activities, and the mutual disclosure of the vulnerable emotional self to the conjugal other. Miriam's words expressed it well: "it was like we had one name, one thought."

In contrast, precolonial Huli philosophies about marriage and marital intimacy were underpinned by an ethic of what I call distant intimacy-intimacy achieved and sustained by avoiding excessive psychological and spatial closeness. Huli men tend to feel that distant intimacy is a better way of doing marriage, while Huli women tend to aspire to making their marriages more companionate. Women associate companionate marriage not only with emotional attachment between spouses, but also with true friendship between them, equal (or almost equal) participation in household decision-making, greater loyalty to each other rather than to their natal families, sexual fidelity, and monogamy (as opposed to polygyny). They also view it as offering them important practical benefits, such as being able to exert more influence over a husband and his resources. And while some men crave and appreciate proximate intimacy with their wives, many also associate it with the loss of male autonomy and privilege. One way to think 
about the recent history of marriage among the Huli, then, is as a story about a contested, ambivalent, fitful, and sometimes violent shift from distant intimacy towards proximate intimacy.

\section{PROXIMATE INTIMACY AND DISTANT INTIMACY}

Of all the narratives I have collected about Huli marriages from 2004 to 2013, Miriam's is the one that most aligns with the companionate marriage model, particularly in terms of emotional closeness being at its center (at least as this marriage was experienced by her; her husband may or may not have had this same affective experience). This emotional intimacy was achieved and reinforced in a number of ways: through choosing each other, living in the same house, sleeping in the same room, conversing pleasurably with each other, building businesses together, and engaging in what she experienced as adventurous and mutually gratifying sex.

As noted above, this model represents a profound departure from precolonial and early postcolonial marital philosophies and practices. Participants in my 2004 research were asked to describe the structure and composition of their childhood household, and to compare it to their own marital household. Twenty-two of the twenty-five women I interviewed said that their fathers and mothers had lived in separate houses, sometimes even on different clan territories, and many said that they rarely saw their fathers when they were children. In contrast, twenty-three of the twenty-five women lived with their husbands and children in one house, representing a dramatic change in household structure over just one generation. Typical of their descriptions of their childhood households were statements like these:

How my father lived or what he ate, I never knew. He had his own house and fields. ... When my father wanted to talk to my mother, he would stand outside her house with his back to the door. He wouldn't look at her. He wouldn't go inside her house or even come close to it. He didn't stand face-to-face with her and talk to her. (Jessie)

My father slept in his own house, and we didn't see him very often. We saw him when it was time to kill a pig for a feast or a compensation payment. At that time, men were men. Very different from now. They didn't sit around and talk with their wives and children, or joke around with them or play with them or do little things to make them happy, make them laugh. My husband isn't like that. He went to school, and he knows the new ways of doing things. He spends lots of time with our children and me. (Gabby)

The men interviewed in 2004 made very similar generational contrasts, though more of them expressed anger and resentment about rarely seeing their fathers, and they also attributed their fathers' absences to labor migration, and not only to there being separate residences for husbands and wives. Traditionally, sons are supposed to move out of their mother's house and into their father's house at about age ten, as a necessary stage in their transition to adult masculinity. They can't, of course, if a father isn't there, so it is perhaps not surprising that men felt a father's 
absence more acutely. What emerged from both men's and women's descriptions of their parents' marriages was a model of "distant intimacy" that was already, even when the participants were children, being frayed by male out-migration to work in mines and plantations in other provinces.

The practice of distant intimacy stems from the premise that a man's and his family's health, vitality, and social success depend on men and women, including spouses, eschewing too much corporeal contact. The ethnographic literature about Papua New Guinea often refers to this as "gender separation," and has emphasized men's avoidance or careful management of female substances-menstrual blood, in particular. I instead use the term "distant intimacy" in order to suggest that there may be ways of imagining and enacting attachments to and entanglements with cherished others that do not include constant physical, verbal, and emotional sharing. The men interviewed by my male field assistants in 2004 emphasized the powerful nature and potential danger not only of a wife's sexual fluids, but also of her talk, touch, smell, and breath (Wardlow 2008, 2014). Many asserted that spousal co-residence (living in the same house) caused premature aging in a man because of the mutual porosity of conjugally linked bodies and the consequent damaging effects of excessive intimacy. Breathing in a wife's exhaled breath, hearing her angry talk cut into one's body, inhaling smoke from a fire made from wood she might have stepped over (thereby contaminating it), -all these female bodily emanations were described as "substances" that could move out of a wife's body into her husband's, causing harm.

In addition to concerns about corporeal intrusions, many men worried about the ways in which conjugal co-residence enabled spouses to "know each other too well." To know one's spouse too well was to know his or her desires, emotional frailties, and past humiliations; it was thus to know exactly what to say to cause emotional injury (which was often described as phenomenologically feeling like a bodily injury). And although men most feared a wife's ability to inflict emotional damage in this way, they also spoke worriedly of the reverse-of being so angry that they used their intimate knowledge about a wife to inflict emotional pain upon her. In short, they expressed grave misgivings about proximate intimacy - the psychological closeness that is at the core of companionate marriage. One might be tempted to assume that such concerns are culturally specific to the Huli. However, it is worth considering that they may be inherent in companionate marriage itself. Analyzing "morbid companionate marriage" (i.e., unhappily married couples) in the United States, Candace Vogler notes that many of them were "mired in something like epistemic overkill"- "so profound a knowledge of their spouses' selves that they can silence or push them to the breaking point with the simplest of gestures" (Vogler 1998: 329-30). Such "epistemic overkill"and its potentially injurious consequences-is exactly what Huli (more often men than women) were describing when they talked about the dangers of "knowing each other too well." 
It is impossible to know how "distant intimacy" was subjectively experienced by married couples in the precolonial past, but today, gender separation is motivated by a range of emotions. For some, a selective and partial practice of gender avoidance can be a form of intimate mutual care, and not just a way for men to protect themselves from women's corporeal and affective incursions. The elderly man quoted below had been trained as a youth to rigorously follow gender separation practices, but at the time of the interview lived happily with his wife in the same house:

I joined a school for ibagiya for almost two years when I was young. (Ibagiya are bachelors, and "schools" such as the one to which he refers are called "bachelor cults" in older ethnographic literature. They were intended to train young men in hunting, warfare, and practices for keeping their bodies healthy and pure.) If we broke the rules, the leaders could tell just by looking at our bodies. There was no way to hide from them. We weren't allowed to look at women or even walk on the same trails. We carried special leaves to wipe away women's footprints, and we recited special spells as we walked along to protect ourselves from the smell or footprints women might have left behind. ... I still follow many of these rules: I never accept food from my wife when she's menstruating. We live in one house, but we sleep in separate rooms. We enjoy talking to each other and eating together, but she may not touch my belongings or go into my room. Living together makes us both happy.

Other elderly men and women who maintained the practice of separate marital residences spoke of how the giving of bridewealth joined spouses' bodies so that they became more sensorially attuned to each other, such that one might feel a spouse's illness or injury, even if living elsewhere. A few, for example, spoke of suddenly feeling pain or malaise, viscerally knowing that something was wrong with a spouse, and running to the spouse's house to find that he or she was sick or had been injured. Intimacy in these marriages was not about mutual psychological disclosure or the sharing of affectively laden talk, but rather about phenomenologically joined bodily experience (even across physical distance), mutual corporeal care (through separate bodily practices that nevertheless helped to ensure the other's health), and the vivid imagining of the spatially distant conjugal other.

Some men who had given proximate intimacy a try rejected it when they observed its impact on their marriage, which they often experienced as a loss of autonomy or dominance. For example, one 54-year-old man whod had four wives said:

Although I've seen blue movies (i.e., pornography), I haven't tried to do any of these things with my wives. I think the purpose of marital sex is to have children. This is our custom, and so I have sex the traditional way, with my wife on her back underneath me. Actually, my second wife liked to try different kinds of styles-when I asked her to try things I'd seen in blue movies or magazines, she agreed and she enjoyed it a lot. But I think this is why she became so rebellious and defiant. She liked it best when she was on top.... But then I noticed that my body was getting weaker and weaker. Also I noticed that she was becoming more demanding, and more likely 
to get angry with me, and that she no longer showed me respect. So now I think all these different styles are bad. They are bad for marriage. I really wanted to try all these different things with her, but my desire for this made me confused, and she took advantage of me. So I divorced her.

In this case, mutual sexual pleasure and the proximate intimacy that comes from revealing one's sexual longings upended the customary norms of male dominance in marriage, leaving this man feeling threatened. Significantly, the corporeal and the structural are linked in this narrative, so that a wife's corporeal ascendancy during sex (being on top) becomes her structural ascendency in the marriage, while the loss of male dominance manifests itself not only in the husband's loss of control over his wife's behavior, but also in his corporeal weakness.

Such concerns endure in the present, making men more skeptical and ambivalent about models of intimacy that might threaten male autonomy and dominance. One consequence is that men often seek out male-only or male-dominant spaces and activities (snooker houses, makeshift taverns, dawe anda) as a kind of antidote for too much time spent in contact with a wife.

\section{BUILDING A COMPANIONATE MARRIAGE, AND THE BETRAYAL OF POLYGYNY}

According to women who described their marital relations as companionate, their marriages were forged, not only through mutually pleasurable sex or intimate conversation, but also through feeling that they and their husbands were working together as a team for upward mobility. Miriam was proud, for example, that her husband trusted her to run their trade store when he was away: their relatively egalitarian economic partnership confirmed for her that their relationship was special. Helen's husband, who worked as a driver in the tourism industry, was able to get her a job as a hotel maid, and, although theirs had been an arranged marriage, they quickly became very emotionally close, a closeness that Helen attributed to the fact that they pooled their resources and decided together on significant purchases:

[Were you able to sit down and talk with your husband? Did you become friends?] Yes, we became friends. We would walk around town together, and go shopping together. When I was forced to marry him, I was unhappy and angry. But once we moved to - , and I was working and I had my own money, I was happy. He got me a job, so I was happy with him. And we saved some money to buy a block of land. We talked, we joked around. [What did you like to talk about?] We were happy when we would talk about saving our money and moving back to Tari to start a little business together. We would talk about the future-about saving money to buy chickens and start a little business.

Jessie, another woman I interviewed, similarly became very close to her husband through mutually pleasurable sex and joint egalitarian strategizing for upward 
mobility. Unlike Miriam's marriage, which was formed by choice, or Helen's marriage, which was arranged, Jessie's isn't easily categorized. Her family had been pressuring her to become the second wife of a wealthy businessman, whom she had never met, when she received a letter from the man who became her husband, the foreman of a road crew that had been working nearby:

And the letter said, "Jessie, why are you hanging yourself up on this old man who already has a wife? (The verb hangamapim - to hang something up — can also mean to become attached or obligated to someone.) Have you met his wife? Have you thought about what your future will be like? Just wait a few days, and I will bring the same amount of bridewealth. If I don't, go ahead and marry him." [Did you know him?] No! I'd seen him working on the road, I knew his face, but we'd never spoken. I hadn't thought of him as a possible husband. I didn't know he was interested in me, and he only told me when he realized I was about to marry someone else.

Faced with a choice between two men she didn't know, one much older and married, and the other her age and unmarried, she "chose" the latter. Like Miriam and Helen, the emotional intimacy she had with her husband was accomplished in part through working as an economic team: he gave her some of his wages to invest in buying and selling betel nut:

We made a lot of profit, and eventually I was able to invest in selling second-hand clothes and in raising chickens. We made a lot of profit from all our little businesses, and we were both very happy. We even made enough money so that we could buy a used car and a block of land. At the end of each day we would sit with our children and we would all count the money together. We would have a huge pile of coins and notes, and we would make smaller piles all worth K50 or K10 or K20. And we would talk together about what to do with it - this much for shopping, this much to save for the car, this much to buy more betel nut, this much for school fees. Like that.

Like Miriam, both Helen and Jessie were shocked when they learned their husbands had taken second wives. In the 2004 sample as a whole, the fathers of eighteen of the twenty-five women had two or more wives, so polygynous marriage was something almost all of them had grown up with, and arguably knew to expect. However, Miriam, Helen, Jessie, and a few others all had believed that their marriages were different from their mothers': they lived together with their husbands, they slept in the same room, they enjoyed sex with each other, they cooked and ate together, they planned, budgeted, and strategized together, and so on. In other words, they all felt they had achieved a degree of closeness, trust, and partnership with their husbands that was incompatible with polygyny. When they imagined the future and strategized with their husbands for how to accomplish specific goals, polygyny was not what they envisioned and was not part of the discussion.

These women felt betrayed in multiple ways when their husbands married second wives. Unsurprisingly, they felt a betrayal of the emotional intimacy and loyalty they thought they had established. They also felt a betrayal of their sense of 
being modern. Although everyone in Papua New Guinea knows that wealthy and powerful men, especially those from Highlands provinces, often take more than one wife, not all cultural groups in Papua New Guinea practice polygyny, and it is increasingly associated with being backwards, uneducated, and un-Christian. Thus, some women experienced a husband's taking a second wife as a humiliating temporal dislocation into a less civilized state. And since they were sometimes sent "back to the village," while the second wife remained with the husband, this temporal dislocation could become a very real spatial and economic dislocation. Finally, some women expressed a sense of having been betrayed in an additional temporal way: they felt that they and their husbands had been traveling along the same life path, and when a husband took another wife, it was as if he had abruptly left this shared path and reinvented himself as a newly young person with an array of life choices ahead of him. Alice, mother of three, and one of the few women who said she had married her lawini (her first true love) and continued to love her husband, had this to say about her husband's plan to marry another wife:

We married when I was young and he was young. The same. We had children together and we have gotten older together. So why should he suddenly think he can turn young again and act like he is sixteen and take another wife. He can't look at me and decide that I am old but that he is suddenly young again! No! So I hit him. And I told him if he married a younger woman I would go have sex with a younger man. If he thinks he can be young again, so can I. But then he said he would cut my vagina if I did that, and I think he meant it. So I stopped saying that.

In sum, women's bitterness stems not only from feeling emotionally betrayed-particularly acute when one thought one's marriage was based on having "one name, one thought"-but also from the gendered unfairness of men's socially sanctioned ability to embark on a new life and to experience again the excitement of youthful desire and attachment. Being suddenly cast into the humiliating "savage slot" of being in a polygynous marriage only exacerbated this feeling of betrayal.

Marrying more than one wife is considered Huli men's right, and simply something most successful men do, unless they are devout Christians. Nevertheless, their sometimes underhanded ways of going about it indicate its increasingly contested nature. For example, Jessie's husband took another wife when she returned to Tari for a few months after her mother died. That he never came for the funeral and took advantage of her absence to surreptitiously marry a second wife seemed like the ultimate betrayal to her. Helen's husband lied to her and initially said his second wife was a cousin who needed a place to stay for a while. She was furious that she had welcomed this woman into her home, cooked for her, and had even given her some money, only to learn later that her husband had given bridewealth for her and was building her a house on a block of land that Helen had helped to purchase. 
Men, unsurprisingly, view polygyny quite differently-the element of betrayal pales before its value as a strategic move, a source of prestige, and a display of powerful masculinity. Like the women, most of the men interviewed in 2004 had polygynous fathers, and although some resented a father's inability to pay the school fees of all of his children (for men this seemed to be the one significant and growing deterrent to polygyny), most spoke with pleasure of belonging to a large extended network of half-siblings. Many did not make much of a distinction between their own mother's children and the other wives' children, referring to all of them equally as brothers and sisters. Those whose fathers had three or more wives expressed pride at being the son of a man who was widely known to have many wives, children, pigs, and areas of land on a range of clan territories. Being able to marry more than one wife both demonstrated a man's wealth and might enable him to become even wealthier if his wives were good pig herders or were able to make a success of selling betel nut or second-hand clothes. Politicians were also more likely to court polygynous men with many adult children, since it was assumed that if the patriarch of a large, polygynous family directed everyone to vote for a particular candidate, they all would. Where monogamous marriage suggested a constricted sociality and was associated with an unmasculine Christian piety, polygynous marriage was associated with an admirable embrace of masculine desire for sex, social expansiveness, and political influence.

Wealthier men who had, or were angling for, leadership positions often married quite strategically so as to consolidate wealth or expand social connections. For example, Jethro, a young man I knew from my doctoral fieldwork in the 1990s (mentioned in chapter 1), had claims to a large number of the electrical pylons running from Hides to Porgera, which provided a handsome annual income. He made a point of marrying Daisy, whose older brother Monty had made money from buying and selling gold during the Mt. Kare gold rush (Clark 1993, Vail 1995, Biersack 1999, Wardlow 2001) and had invested it in trade stores and PMVs. Together the two men were able to expand their businesses into the Porgera area, and Jethro solidified his social and entrepreneurial connections there by taking a Porgeran wife who belonged to a landowning clan. Jethro's older sister, Theresa (see chapter 1), further expanded their social network there when she married a Porgeran policeman. Sadly, all the people in this story-Jethro and his two wives, Monty and his wife, and Theresa-became infected with HIV, and only Theresa was still alive in 2012, when I interviewed her.

These brother-sister pairs (Monty/Daisy, Jethro/Theresa) were two of the cases of siblings infected with HIV that made me suspect that HIV was significantly more prevalent in the Tari area than in Papua New Guinea as a whole. However, it is important to note that the HIV infection of these two sibling pairs can be seen as strongly socially determined: because polygyny is an important entrepreneurial strategy for enhancing claims to land and recruiting partners for business ventures, an economic tie to a family can also be a sexual tie. Jethro, for example, 
had a sexual tie to Monty, both in the sense that he married Monty's sister, but also because, as business partners, they went out drinking together at the same hotel bars and joined the same sexual networks. Very likely, they slept with some of the same women. Moreover, business opportunities are most available in resourceextraction sites where, as discussed in chapter 1, landowners have preferential access to contracts for construction, catering, cleaning services, and other business opportunities, and can also exert control over which outside small businesses come into the area. Thus, an economic strategy (expanding one's PMV services) is also often a geographic strategy (expanding them into the Porgera area), which is also often a social strategy (drinking and womanizing with potential Porgeran business partners), as well as a marital strategy (taking a Porgeran woman as a second wife in order to gain permission for expansion of the PMV business). For entrepreneurial men, then, an economic strategy can easily become an array of HIV exposures for themselves and their wives.

\section{MEN'S EXTRAMARITAL SEX}

If polygyny is one source of conflict in marriage, as well as a source of HIV vulnerability, men's extramarital interactions are another (see also Lepani 2008). Twenty-two of the twenty-five women I interviewed in 2004 had been married to husbands who engaged in extramarital sex, though the number of other partners their husbands had likely varied tremendously. Ten of these women believed they had been infected with a sexually transmitted infection by their husband. (I say "believed" because I did not examine their clinic books for a diagnosis, and thus it is impossible to be sure that these were all STIs and not some other kind of vaginal infection.) And, as mentioned at the outset of this chapter, at least twenty-two of the thirty HIV-positive women I interviewed in 2012 and 2013 had been infected by their husbands. ${ }^{3}$

It is important to emphasize that little in precolonial Huli society promoted or condoned extramarital sex by either women or men. As discussed earlier, men were taught to protect their health and masculine vigor by living separately from women. Failure to abide by gender separation was said not only to compromise a man's health, but also the well-being of his male kin and allies, particularly if they were about to make war, and even to sap vitality from their land. Pre- or extramarital sex is considered a kind of theft from a woman's natal family or husband, and usually causes "trouble" (retaliatory violence, demands for compensation). And because of the spousal corporeal porosity discussed earlier, wives and children are said to experience malaise, weakness, and sometimes worse when husbands "jump over them" (kalapim ol; that is, stray sexually). Indeed, men are often quite anxious about how their extramarital forays might negatively impact or be "felt" by their wives and children, and some make a point of drinking and washing in the purest mountain water they can find before coming home, hoping that this will act 
as a kind of cleansing prophylaxis against any damage to the household that might result from their liaisons. In short, when seeking to explain why a high proportion of married men might have extramarital sex, precolonial philosophies and practices regarding sex provide no answers; if anything, they worked to discourage, prevent, and punish extramarital sex.

Of the many changes instigated by the colonial and postcolonial periods, most important in fostering extramarital sex has been male labor migration, originating with the Highlands Labor Scheme, implemented in 1950 to help Australian colonial plantations recover from the devastation of World War II by bringing men from the densely populated inland, mountainous areas down to the coast for short periods of labor (Ward 1990). The economic trajectory of the Southern Highlands region, including the Tari area, was profoundly shaped by this scheme. The initial areas of labor recruitment-the Eastern and later Western Highlands regions-were also the areas where families were encouraged to establish their own coffee gardens in order to supplement the output of Australian-owned plantations. By the early 196os, indigenous smallholder coffee production had overtaken the colonists' plantation production, and by the mid 1960s it had exceeded Australia's export quota (Stewart 1992, Good 1986, West 2012). Consequently, in order to limit coffee production and ensure the availability of labor for coastal plantations, the colonial administration extended its labor recruitment to more remote highlands areas, such as Southern Highlands Province, and never developed these areas as coffee producers (Strathern 1982, Connell 2005). From the mid 1960 s until 1974, when the scheme ended, most of the workers came from Southern Highlands Province (Ward 1990, Harris 1972, Fitzpatrick 1980). High levels of male out-migration from the area continued even after this period: migration data from 1982, for example, show that in some areas around Tari, approximately 45 percent of men between the ages of 20 and 39 were absent from their home communities (Lehmann 2002, Lehmann et al. 1997).

This history-of being far from Highlands centers of economic power, of never developing the coffee economies that Eastern Highlands Province and Western Highlands Province did, and, especially, of spending often long periods away from home in search of economic opportunity-has shaped Huli discourses about themselves as a people, as well as notions of masculinity. For example, throughout the 200os, I often heard Huli claim that they were "the slaves of the nation" because of their past history of helping other provinces to develop (while their own province languished) through their labor for plantations, infrastructure projects, mines, and so on. And, migration in search of economic opportunity is now an expected part of masculine experience for Huli men. Of the fifty-four men my male field assistants interviewed in 2004, thirty-one (57 percent) had spent six months or more working in another area of Papua New Guinea, typically in mines, on tea or copra plantations, or as store clerks or security guards in urban centers. Many described how migrant male friendships were forged and maintained through drinking, 
buying sex, joking about sexual liaisons, and sharing information about sexual partners. A number of them complained about the peer pressure to engage in these activities, and lamented the guilt they felt about spending money on personal pleasures instead of sending money home (Wardlow 2009, Hirsch et al. 2010).

But if being far from home and in the company of other male migrants often initiates what might be called a man's extramarital sexual debut, this does not mean that extramarital liaisons are confined to places away from home. And because of the disappearance of other ways for women to make money in and around Tari, it was easy to find sex for sale there by the 2000s, as discussed in chapter 2 .

\section{WIVES REACT: VIOLENCE AND BEKIM BEK}

Gender inequality among the Huli allows men great freedom of mobility and little obligation to account for their time spent away from home, privileges generally denied to wives. Thus, as one AIDS educator announced to her all-female audience when trying to counter their religious objections to her speaking publicly about condoms: "What? You think you can carry your husband's cock around in your string bag? Men go where they want and do what they want, and they take their cocks with them." Unable to prevent a husband's extramarital forays, many wives have to decide how to respond to their knowledge about them. In some cases, women respond by ignoring their increasing suspicions or by pretending they don't know, until circumstances, such as experiencing symptoms of a sexually transmitted infection, provide them with a morally irreproachable rationale (protecting their fertility) for broaching the subject.

Angry or even violent confrontation was at least as common a response to male infidelity. Although male privilege explicitly sanctions many freedoms denied to women, it does not include anguatole or kelapim (Huli and Tok Pisin, respectively, for jumping or stepping over someone, euphemisms for extramarital sex), and Christian missionization has reinforced the idea that extramarital sex is immoral. Moreover, unlike in other cultural contexts where a husband's extramarital sorties are often attributed to his wife's supposed failings, and are thus a source of shame to her (Hirsch et al. 2010), Huli men's affairs are generally attributed to their own desires and weaknesses. Thus, many Huli women show no compunction about making a spectacle of a husband's dalliances by demanding compensation in village court or by physically attacking him and his partner in public. Indeed, many of the women I interviewed seemed to fear losing face if they didn't expose a husband's affair and attempt to punish him for it. Eleven of the twenty-two women I interviewed in 2004 who said they knew their husbands had engaged in extramarital sex spoke of responding violently.

Miriam, whose story began this chapter, physically attacked her second husband (the one she had moved in with after meeting him at a dawe anda) when she learned he continued to have sex with other women: 
[Has there been a time when your husband made you very angry?] Yes. He had sex at a dawe anda. I told him not to go, but he went anyway and had sex with a woman I know. And then they continued having sex for three months. He would sleep at our house, but go have sex with her during the day. And I lost weight, and I was tired all the time. I just wanted to sleep. I was very weak. And finally I confronted him. I said, "I think you must be having sex with another woman." Because some women told me that if your husband is having sex with other women, you will feel tired and weak. So I asked him, and he denied it. But one day I followed him, and I saw him ask this woman for money so that he could play cards. A man only asks his wife or sister for money, so I picked up a stick, ran up to him, and whipped him in the face and head. I was really angry with him then.

Maria, a woman who looked to be in her late thirties, also responded violently when she was confronted with her husband's infidelity, though her marriage had long been conflict-ridden. She described herself as having grown up in a very traditional family. Her father had five wives (her mother was the second wife), and he lived in his own house:

He was a man who followed custom. He rarely visited his wives, and when his wives gave birth, he never came to look at the baby. And his house wasn't nearby-it was very far away from our house. We never saw him.

When she was in grade one, her father informed her that she would be marrying an acquaintance of his:

I didn't know him. My father knew him. My father just came and announced that I had to go marry this older man. ... I was very young. Only grade one. I didn't have breasts yet. I hadn't started menstruating. I was married to my husband for two years before I got my period. (Huli children often don't start grade one until age ten, and in the past, when Maria would have been in school, the starting age was often older.)

In fact, Maria didn't meet her husband until two years after marrying him because he was living in Port Moresby, and his family gave bridewealth to hers in his absence:

When he came back from Port Moresby I wanted us to have separate rooms. I was very young, and he was much older, but he said no, and he insisted on having sex. He found it very difficult to get inside me. I bled, but he couldn't get it all the way in. To make it more slippery, he tried lathering his penis with soap, but that was very painful and it didn't work. Then he lathered his penis with cooking oil, and that worked. And I got pregnant very quickly, which made him angry because he wanted to keep having sex with me, and I said no. This is our custom, and I was afraid that if we kept having sex it would damage me or the baby. So I ran home and stayed with my parents. But he sent the police to fetch me back.

Throughout their marriage they argued and sometimes physically fought about sex: she showed me small scars on her head, legs, and arms where he had cut her 
with a knife for refusing sex, and she had one very long, thick scar on her arm from when he had tried to cut her with a knife and she had thrown up her arm in defense:

But I hit him too. I stabbed him too. Once I stabbed him in public, in front of Bromley's (Tari's largest store through the 1990s until 2002, when it was looted and then closed; see chapter 2). I was retaliating because he had almost cut my arm off. He had to go to the hospital for stitches. I used to be a bad woman (meri nogut, which literally means a bad woman, but is usually used to mean a fierce, unforgiving woman): if he cut me, I would cut him back. If he poked me with a knife, I poked him back. I only thought about getting revenge. But it was all because of sex. He wanted sex all the time.

Although she resisted what she experienced as his excessive demands for sex, Maria was nevertheless enraged when she came upon her husband having sex with another woman one night:

He had sold a pig and had money to spend. So he went to a dawe anda near our house and found a woman there. And I discovered them. . . . I thought I heard our pig squealing, and I grabbed a large bush knife. I thought someone was stealing our pig. So I ran with a big bush knife, and I came upon the two of them bare naked and fucking [You saw them naked?] Yes, I saw their asses and their other sexual parts. I was so embarrassed and angry. I yelled, "What are you doing? You're fucking this woman?" And my husband yelled, "You always say you don't want to have sex, so yes, I found someone else to fuck." And I tried to cut the woman with the bush knife, but he grabbed me and held my arms to my sides. And I yelled at him, "Don't touch me. You just had sex. Get away from me. Don't touch my skin." And he wrestled the knife away from me and threw it aside. So I grabbed the woman's clothes and her bag and threw them into the stream nearby. She was naked and had no clothes.

And then I started yelling as loud as I could. And a bunch of men came running, and they saw her standing there naked, and then they held her legs and arms and took her away and fucked her. [Are you saying they took her away and raped her? (I'd been chuckling at her throwing the woman's clothes into a stream, but you can hear the shock enter my voice.)] Yes, they raped her. There were lots of men and just her, and she was naked. [Why did they do that?] Because I told them to. When I was yelling for them to come, I said, “There's a woman in my pig house. You all take her and fuck her. She's looking for men.” My husband didn't go with them. He came back to my house, but I told him to go away. I told him he fucked around with passenger women, and I didn't care if killed a pig for me (that is, gave her compensation for "jumping over" her). I told him he was a gonorrhea man and I didn't want to see him.

That women expose other women to men's sexual violence is rare, but does happen. Recall from chapter 1, for example, that Kelapi's uncle's wife conspired with their Porgeran landowner patron to abduct her and take her as his wife. Women may do this for pragmatic reasons, as in the case of Kelapi's aunt, who wanted 
to maintain good relations with their landowner patron. Or they may, like Maria, want to punish women they feel have humiliated them. Also important in Maria's case, I think, is the chronic conflict and violence that she had experienced in her marriage, starting with what amounted to marital rape at a very young age, which led her, according to her own account, to become more angry and violent herself. To be clear, Maria did not actually witness the woman being raped by the men she had summoned with her shouting, and Huli women's narratives about violent confrontation are often characterized by a triumphalist tone (Wardlow 2006a) in which a female narrator's successes are amplified and her nemesis's iniquitous nature, and consequent downfall, are exaggerated. In such narratives, the humiliation of the female nemesis, often through her public nudity (Wardlow 2006a: 91), is emphasized. Nevertheless, regardless of how Maria might have embroidered this narrative, her tacit assertion is that sexual violence is a morally acceptable or even appropriate retribution against a husband's illegitimate sexual partner, particularly if the woman attends dawe anda or is a passenger woman. Maria's attitude indicates her fury about her husband's bringing a sexual partner onto their territory, an act that both polluted the land and demonstrated his disregard for her. This narrative also indicates the way that women who are categorized as sexually transgressive can precipitously be thrust into an abject status that makes them be seen as deserving recipients of punitive sexual violence. In other words, despite an apparent increase in tolerance for women who engage in transactional sex in Tari (see chapter 2), in fact it takes very little to expel such women from a moral space of safety (see also Kelly-Hanku et al. 2016).

Women also sometimes respond violently to a husband's decision to marry an additional wife. Helen, whose husband had found her a job as a hotel maid, said this, for example, about discovering that her husband's "cousin" was actually his second wife:

There were two incidents when I cut that woman with a knife, and three times that I cut him with a knife. Once he had to go to the hospital and get eight stitches, and another time he had to get four stitches. Finally I said, "I might end up killing you, and then I would be causing a lot of trouble for my kin (meaning they would have to pay compensation for her murdering him). So tell the business to transfer you to some other hotel. We shouldn't live in the same place-I might end up dead, or you might end up dead, or she might end up dead. And then we are causing trouble for our kin."

While women often represent their physical aggression towards a husband and/ or his extramarital partner as primarily an expression of uncontrollable rage, it does, in fact, have a purpose: it is intended to sever the extramarital relationship and drive the other woman away. Recall that when her husband's first wife attacked Theresa (see chapter 1), who was married to a policeman in Porgera, she responded with escalated aggression and compelled the other woman to leave. 
Responding with bekim bek - revenge sex-was not quite as common as women's violent reactions to men's philandering. Seven of those in my 2004 sample of twenty-five married women responded to their husbands' infidelity-or, as in Miriam's case, his decision to take a second wife-with bekim bek. Tani, for example, had heard rumors that her husband was sleeping with her cousin, and

I wanted to see for myself. So one day when I heard they were at it again I went and looked. Our house was a haus kapa (literally, house copper; that is, a modern house with a metal roof), and it had a window, so I could look inside (most "bush houses" - that is, houses built with the wood of local trees and grass-do not have windows). And there they were, drinking Gold Cup (whiskey) and listening to the radio.... So I left and went to stay with my kin, and I kept thinking and thinking, "How can I get the bridewealth returned? How can I get the bridewealth returned?" (In other words, she wondered how she might be able to divorce her husband, which would require the return of at least some of the bridewealth he had given for her.) And I realized it would be impossible. Because if your family chooses your husband and it goes badly, then they might return the bridewealth. But if you choose your own husband, like I did, then they won't. They will say, "You wanted him. We didn't choose him, you did. So stay with him." So I thought, "Okay, he wants to fuck my cousin, I'll go fuck his cousin. I will retaliate (Bai mi bekim bek).” And there was this man from $\mathrm{T}$-, a really fat man. He was one of my in-laws, but he'd asked me to marry him when I was younger. I had refused because he already had a wife. But I went and found him, and he greeted me politely, but I just said it to him directly: "Your cousin is fucking my cousin. What do you think?" And he said, "Let's go." So I went and stayed with him for two weeks and had sex with him.

Since divorce seemed out of reach, Tani was aiming for exact adulterous equivalence: a cousin for a cousin. Anthropologists have often written about the Melanesian ethic and logic of reciprocity and equivalence, typically when analyzing gift exchange between individuals and groups. How this ethic can also inform interpersonal, and even sexual, relations has been less explored, however. Often women describe themselves as aiming for an affective equivalence: that is, they want to cause the same kind and degree of emotional pain that they themselves have experienced. In this case, Tani wanted to injure and insult her husband in the exact proportion that he had hurt her; moreover, she anticipated that when the inevitable fight about her behavior erupted, she would be able to assert this equivalence, and thus argue that she and her husband were even in terms of having wronged each other. She wanted to humiliate him by rubbing this adulterous equivalence in his face, but also wanted to limit the physically violent retaliation from him that she felt would be merited if she had gone beyond this equivalence and wronged him to a greater degree than he had wronged her.

It is also important to note that Tani, while aiming for equivalence, also chose her extramarital sexual partner safely in the sense of opting for someone familiar: an in-law who was also a former suitor. In contrast, most of the other women 
who resorted to bekim bek chose partners unknown to them, the first man to come along, as it were-or at least this is what they told me. Acting impulsively and showing little deliberation (at least in recounting it, and perhaps in their actual behavior) was a way of demonstrating their extreme rage and its uncontrollable nature.

\section{CONCLUSION}

In the public health literature about HIV, polygyny is often treated as a risk factor: it is referred to as "marital concurrency," which is conceptualized as a form of "sexual concurrency" - that is, having more than one sexual partner at the same time (as opposed to having serial sexual partners one after the other), a mode of sexual partnering that is thought by many epidemiologists to pose greater HIV risk (Halperin and Epstein 2004, Mah and Halperin 2010). Polygyny is assumed to be hazardous because if one of the spouses contracts HIV, it may spread to the others: a husband can infect not just one wife, but two or more. This framework assumes a particular model of polygyny in which a husband continues to have sex with his existing wife or wives after taking a new one. While this is often true, there are, in fact, a variety of ways in which polygyny unfolds among the Huli, particularly as it has become more controversial and contested. ${ }^{4}$ In some cases, when a man takes a second wife, the first wife will refuse to continue having sex with him, citing fear of disease, anger about the loss of resources for herself and her children, or simply, "I've given you children, now it's her turn."

It is clear from my interviews that (1) marital concurrency isn't necessarily sexual concurrency and, in fact, may sometimes look a lot more like serial sexual partnering, and (2) polygyny, at least among the Huli, can take such a wide range of lived forms that it cannot be considered a stable and coherent independent variable or risk factor. Also problematic is that the public health framework of "marital concurrency" assumes a kind of temporal stasis, in which polygyny is treated as a person's stable trait. A more dynamic approach (that is, a more ethnographic approach) would examine how all the spouses in a marriage enact and respond to polygyny. It could very well be that polygyny poses increased HIV risk, but not necessarily because the infection of one spouse leads to the infection of all. Rather, a woman's anger about a new wife might drive her to bekim bek with multiple partners, exposing her to HIV. Alternatively, or additionally, abandoned by her husband as his affections turn towards his new wife, she might engage in transactional sex in order to provide for herself and her children.

In addition to the dramatic economic and political upheavals discussed in chapters 1 and 2, Huli have also experienced a great deal of upheaval in the marital domain. A generation ago, most married couples lived in separate houses and saw little of each other, but now most live together in one house-an enormous change, not only in the structure and composition of households, but also in spouses' 
affective lives. Many Huli find this challenging-perhaps especially the current generation of men, who have been raised to be wary about excessive bodily contact with women, feel trepidation about "knowing each other too well," and are often unprepared for managing the challenges of this kind of marriage.

These challenges are exacerbated by men's and women's differing desires and aspirations for marriage. While both men and women want to be able to choose their own spouses, women typically have greater aspirations that their marriages will be companionate-that is, emotionally fulfilling and characterized by a real partnership of shared goals, joint decision-making, and communication about sex and reproduction. They hope that this kind of partnership precludes polygyny. Men, while often enjoying the pleasures and benefits of a shared house and a wife's companionship, are reluctant to relinquish household authority, absolute freedom of movement, the pleasures of extramarital relations, and the rewards of polygyny, which include prestige and the potential for creating a large, economically powerful, and politically influential family. Women like Miriam, Helen, and Jessie hope, and sometimes allow themselves to assume, that what they experience as a foundation of intimacy, trust, and good communication will protect them from polygyny. However, women like these may be those most at risk of finding themselves in a polygynous marriage: the upward mobility and economic success they have achieved as economic partners with their husbands contribute to their feelings of joyous connection, but this very success enables their husbands to take additional wives. In point of fact, of the twenty-five married women I interviewed in 2004, eighteen of their first marriages were either initially or eventually polygynous, by which I mean that they either married as second wives or they were first wives whose husbands eventually took one or more additional wives.

In light of the violent conflict that often erupts over clashing marital expectations, it is not surprising that organizations like Population Services International have developed marital training workshops to help couples try to understand each other's perspectives and communicate in ways that reduce the likelihood of physical aggression. It is tempting to analyze such workshops as biopolitical interventions aimed at producing compliant, affectively self-regulating marital subjects. The workshop handbook does, after all, employ exercises that encourage participants to be more self-reflective about their emotions and gives them lots of practice in translating explosive negative feelings into less volatile verbal formulations. In short, seeing these workshops through a Foucauldian lens would be analytically fruitful. Nevertheless, given the anger and desolation expressed by many men and women about their marriages in the 2004 interviews, it would seem a good idea to equip couples with skills that might help them strive for the companionate marriages to which many aspire. In essence, such workshops "de-naturalize" companionate marriage by acknowledging that specific, difficult skills are required to make it work, and that many couples the world over find it challenging. 
The idea, however, that such workshops might have a significant impact on HIV vulnerability seems highly optimistic. As discussed in this chapter and the previous two, there are many factors that shape men's and women's sexual behavior, including the long history of Huli men's migration out of Tari to find work and the economic downturn that drove many women to engage in transactional sex. Workshops like the one offered by PSI presume a couple in which both partners are present and co-habiting-not estranged by polygyny or migrant labor-and thus do not directly confront the structural factors that have created HIV vulnerability. 